\title{
COMUNICACÕES
}

\section{Essential oils inhibit Colletotrichum gloeosporioides spore germination}

\author{
Daniele Maria do Nascimento ${ }^{1}$, Paula Leite dos $\operatorname{Santos}^{1}{ }^{\mathbb{0}}$, Adriana Zanin Kronka ${ }^{1} \mathbb{0}$
}

${ }^{1}$ São Paulo State University (Unesp), School of Agriculture. Av. Universitária, 3780 - Altos do Paraíso - Botucatu, São Paulo, Brazil. Zip Code: 18610-034.

Autor para correspondência: Daniele Maria do Nascimento (daniele_ocz@hotmail.com)

Data de chegada: 11/07/2018. Aceito para publicação em: 17/08/2019.

$10.1590 / 0100-5405 / 207645$

Anthracnose, caused by a complex of species belonging to Colletotrichum genus, is one of the most destructive diseases during the production of pepper fruits. Hong et al. (5) reported that one of the main causes of the drastic increase in anthracnose among peppers grown in open fields was conidial dissemination from infected to healthy fruits due to the rain and the wind. The spores attached to the host surface produce the germ tube and initiate penetration. At this stage, the pathogen is vulnerable and has not yet started the infection itself; thus, strategies to prevent spore germination must be adopted at this moment.

The ability of essential oils to inhibit fungal spore germination has been reported by several authors. Considering Colletotrichum genus, successful studies have been conducted with Hyptis marrubioides, Aloysia gratissima and Cordia verbenacea essential oils on the in vitro inhibition of Colletotrichum truncatum spore germination in common beans (7), as well as with Melaleuca alternifolia, Mentha piperita, Pimpinella anisum and Rosmarinus officinalis essential oils on $C$. gloeosporioides isolated from papaya (2).

This study aimed to investigate the in vitro action of essential oils on C. gloeosporioides, the causal agent of anthracnose in pepper crops, evaluating their control on the reproductive stage of this pathogen through conidial germination inhibition.

Conidial germination assays were carried out in Petri dishes (2.5 $\mathrm{cm}$ diameter) containing a thin layer of agar-water culture medium. The whole culture medium surface was covered with a suspension of
$125 \mu \mathrm{L}$ conidia $\left(7 \times 10^{4}\right.$ per $\mathrm{mL}$ adjusted by hemocytometer) obtained from a 7-day-old culture of C. gloeosporioides isolated from pepper, and $25 \mu \mathrm{L}$ each essential oil. For each treatment, three replicate Petri dishes were used. After an incubation period of nine hours in the dark and at $25{ }^{\circ} \mathrm{C}$, germinated and non-germinated conidia were stained with lactoglycerol and counted under a microscope.

The results of conidial germination assay are reported in Table 1. C. gloeosporioides conidia were susceptible to all tested essential oils. The adopted dose of the essential oils caused maximum conidial germination inhibition, except for the treatment with $Z$. officinale essential oil, which had $8.38 \%$ germinated conidia.

Our results are similar to other data in the literature, which also suggest that essential oils can inhibit conidial germination. Bonaldo et al. (3) examined the effects of Eucalyptus citriodora essential oil on Colletotrichum sublineolum conidial germination and reported that concentrations of $5,10,20,40$ and $60 \mu \mathrm{L}$ can cause $100 \%$ conidial germination inhibition. Abd-El-Latif (1) demonstrated the ability of Eucalyptus globolus and Cymbopogon citratus essential oils to inhibit Botrytis cinerea and Penicillium sp. spore germination at concentrations higher than $0.6 \%$.

Compared with the control treatment, in which an extremely long germ tube was observed, in the presence of $Z$. officinale essential oil, the germ tube produced by the pathogen was smaller (smaller than the spore itself). Although germination was inhibited, deformations in the spores were not observed when in contact with the essential oils (Figure 1).

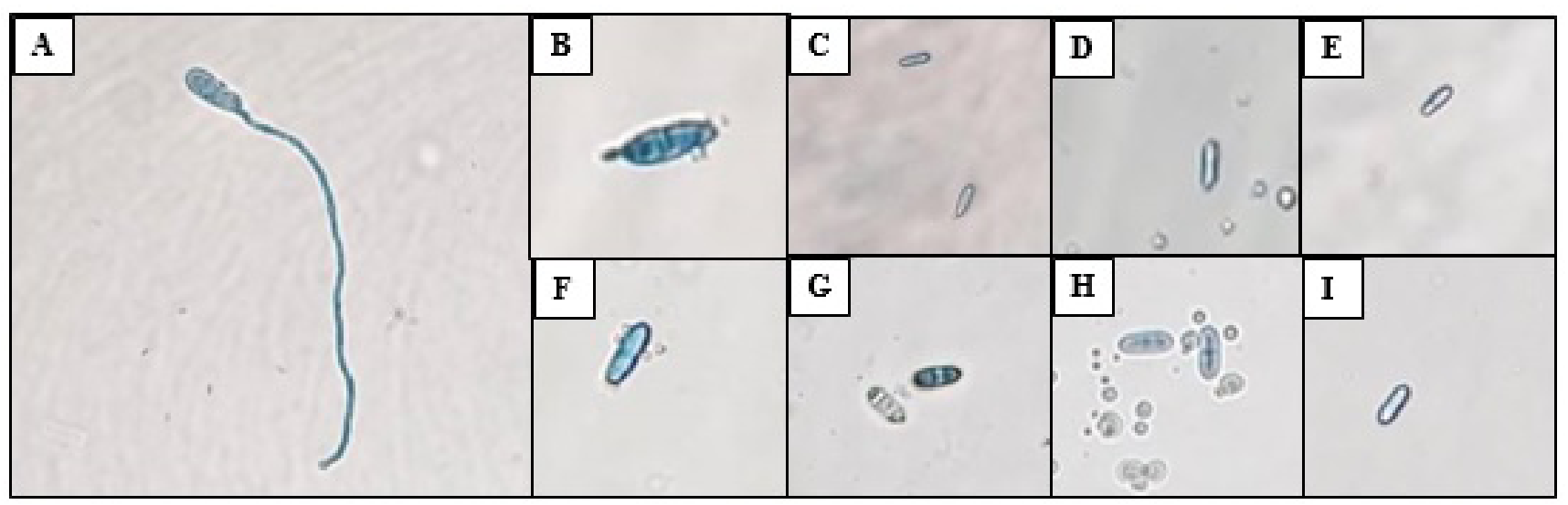

Figure 1. Optical microscopy at 40x magnification of C. gloeosporioides conidia untreated (A) and treated with Zingiber officinale (B); Cymbopogon citratus (C); Piper nigrum (D); Pelargonium hortorum (E); Zyzygium aromaticum (F), Melaleuca alternifolia (G); Corymbia citriodora (H) and Mentha arvensis (I) essential oils. 
Table 1. Percentage of Colletotrichum gloeosporioides conidia germination in the presence of eight essential oils.

\begin{tabular}{cc}
\hline Essential oils & (\%) Germinated conidia \\
\hline Zingiber officinale & a 8.38 \\
Cymbopogon citratus & a 0.00 \\
Piper nigrum & a 0.00 \\
Pelargonium hortorum & a 0.00 \\
Syzygium aromaticum & a 0.00 \\
Melaleuca alternifolia & a 0.00 \\
Corymbia citriodora & a 0.00 \\
Mentha arvensis & a 0.00 \\
Control & b 73.98
\end{tabular}

$\mathrm{a}, \mathrm{b}$ - Means followed by the same lowercase letter do not differ according to Tukey's test $(\mathrm{P}>0.05)$.

When treated with Zingiber zerumbet essential oil, the spores of Aspergillus ochraceus presented deformations, such as ruptures and wrinkling (6). Carmo et al. (4) also observed morphological changes in the spores of Aspergillus species due to Cinnamomum zeylanicum essential oil. These results demonstrate that these substances are able to act directly on the pathogen.

During conidial germination, some metabolic activities such as RNA and protein synthesis, respiration and trechalose breakdown occur. Therefore, essential oils inhibit these activities.

The present study improves the knowledge about the use of essential oils as treatment for diseases. This experiment is the first to test these eight essential oils on conidial germination of C. gloeosporioides (isolated from pepper). Further research should explore the possibility to develop a fungicide.

\section{REFERENCES}

1. Abd-El-Latif, F.M. Postharvest application of some essential oils for controlling gray and blue moulds of apple fruits. Plant Pathology Journal, Suwon, v.15, n.1, p.5-10, 2016.

2. Andrade, W.P.; Vieira, G.H.C. Efeito dos óleos essenciais sobre a antracnose in vitro e em frutos de mamoeiro. Revista Brasileira de Plantas Medicinais, Campinas, v.18, n.1, p.367-372, 2016.

3. Bonaldo, S.M.; Schawan-Estrada, K.R.F.; Stangarlin, J.R.; Cruz, M.E.S.; Fiori-Tutida, A.C.G. Contribuição ao estudo das atividades antifúngica e elicitora de fitoalexinas em sorgo e soja por eucalipto (Eucalyptus citriodora). Summa Phytopathologica, Botucatu. v.33, n.4, p.383-387, 2007.

4. Carmo, E.S.; Lima, E.O.; Souza, E.L.; Sousa, F.B. Effect of cinnamomum zeylanicum blume essential oil on the growth and morphonesis of some potentially pathogenic Aspergillus species. Brazilian Journal of Microbiology, São Paulo, v.39, n.1, p.91-97, 2008.

5. Hong, J.K.; Yang, H.J.; Jung, H.; Yoon, D.J.; Sang, M.K.; Jeun, Y.C. Application of volatile antifungal plant essential oils for controlling pepper fruit anthracnose by Colletotrichum gloeosporioides. Plant Pathology Journal, Suwon, v.31, n.3, p.269-277, 2015.

6. Madegowda, B.H.; Rameshwaran, P.; Nagaraju, N.P.; Murthy, P.S. In vitro mycological activity of essential oil from Zingiber zerumbet rhizomes. Journal of Essential Oil Research, Philadelphia, v.28, n.1, p.81-88, 2016

7. Silva, A.C.; Souza, P.E.; Machado, J.D.; Silva, B.M.; Pinto, J.E.B.P. Effectiveness of essential oils in the treatment of Colletotrichum truncatum-infected soybean seeds. Tropical Plant Pathology, Brasília, DF, v.37, n.5, p.305-313, 2012. 